\title{
Homestay Management Programmes in the Area of New Tourism Destination in Petak Village, Pacet
}

\author{
Amalia Mustika, Fachrul Husain Habibie \\ Hotel \\ Sekolah Tinggi Pariwisata Trisakti \\ Jakarta, Indonesia \\ amaliamustika@stptrisakti.ac.id
}

\begin{abstract}
Many villages in Indonesia are visited by both local and foreign tourists, one of which is the village Petak, Pacet. This is a challenge for the local community, government officials and even the intellectuals. The use of the term "homestay" might be different in different countries. In attracting tourists, preparations in all areas are needed, one of which is to provide homestays. The objectives of the research are: The first one is how the homestay program is implemented in Petak Village, Pacet after being given both theoretical and practical subjects, and the second is the challenge in implementing a homestay program where the development of sustainable tourism as cultural social program is implemented in the community, the environment and the effects of the economic situation of the community, and the third is to change the way of thinking of rural communities, where houses can be used as a homestay which is different from boarding houses. The method of this study is a qualitative method, in which researchers attempted to describe the actual condition or state by collecting data and information in the field and explain in narrative form without test hypotheses or make predictions before, while the data collection techniques is using observation, interviews, and documentation. The results of this study are homestay program can be implemented in the village of Petak because most of the houses of the people have meet the homestay criteria based on cleanliness, comfort and security. This means that the culture of rural plots to preserve the cleanliness, comfort and safety has been running well.
\end{abstract}

Keywords - Homestay Management, New Tourism Destination

\section{INTRODUCTION}

The number of villages in Indonesia is about 73.067 (Permendagri No. 6, 2008). Such rural area is potential to be developed into a tourism village, especially rural tourism. Rural tourism development is able to support the efforts of rural poverty reduction by empowering local communities during the village's tourism development. In addition, tourism is a sector that holds crucial role in the region development process, i.e. contributing to the local and community income. This contribution gives local governments an additional income in developing projects and other activities in the area.

Petak is a village in the Pacet District, Mojokerto, and East Java Province. This village is closely associated with the triumph of Majapahit era. This is proven by the presence of several heritage in the future in the form petilasan which is still maintained by the village government Petak, including: inscribed Stone Petilasan in Dukuh Village, Petilasan Kemasan, Watu Omah in the Kembangsore village. One of the ways to attract tourists to the village Petak by introducing local culture, adventure travel, history and interaction with the local community. In attracting tourists, the need for preparation in all fields, one of which is to provide homestays.

The two objectives are taken into consideration when learning about homestay program in Petak Village, Pacet. They are as the following:

a. How is the homestay program implemented in Petak Village, Pacet after being given both theoretical and practical subjects?

b. To what extent is the change in the way of thinking of rural communities, where houses can be used as a homestay not like boarding houses?

The word "homestay" refers to "Pondok Wisata". Which is in accordance with Parekraf Ministerial Decree No. 9 of 2014. The decree further states 'homestay' as the provision of accommodation in the form of residential buildings inhabited by their owners and the utilized portion for rent to tourists by providing opportunities to interact in everyday life with their owners.

Based on (UNESCO) the United Nations Educational, Scientific and Culturan Organization (2009), homestay is a popular type of accommodation in the urban and rural areas in Indonesia, used as a private dwelling house where tourists stay. Some definitions of homestay accommodation are provided as follows:

According to Lynch dalam Sweeney (2008), Homestay is a special term used variously to refer to types of accommodation where visitors of guests pay directly or indirectly to stay in private (commercial) homes, where interaction takes place to a greater or lesser degree with a host and/or family who usually live upon the premises and with whom public space is shared to a greater or lesser degre. While according to Frederick in Seubsamarn (2009), Homestay is a place to stay for tourists or a visiting foreign student who is hosted by a local family. Based on those definitions, Federick 
revealed that the homestay is home to tourists or foreign students who are owned by local communities. Lynch stated that the homestay is a type of accommodation where visitors / guests pay directly or indirectly to stay in private homes, where there is interaction between living with the owner and his family and shared a common room into a public space. According to Asean Homestay Standard, definition of homestay is an alternative tourism where tourists will stay with the host's family in the same house and will experience the everyday way of life of the family and the local community, and then definition of Homestay Provider is local family that offer their house as a homestay.

\section{Homestay requirements based on ASEAN Standard}

a. Accommodation

1) Condition of the house

2) Bedroom and amenities

3) Toilet and amenities

b. Activities

1) Activities offered

2) Tourism attraction at homestay

c. Location

1) Road condition leading to homestay

2) Condition of signposting

d. Hygiene \& Cleanliness

1) Condition of the house (kitchen, room, toilet, surrounding compound)

2) Food preparation and utensils used

e. Safety \& Security

1) Safety features available (railing, emergency kits, etc.)

2) Signposting along the trail

3) Safety personnel involved in the activities

f. Marketing \& promotion

1) Promotion materials e.g. brochure

g. SUSTAINABILITY PRINCIPLES

1) Green facilities available in the homestay

2) Local-made-handicraft

\section{Homestay Concept}

Homestay is one tourist activity utilizing a private dwelling house as accommodation for tourists to stay. In general, when staying in homestay, travelers get room service, food and drinks. One of the advantages of homestay is that tourists can get a chance to mingle with the host's family and get to know the culture and traditions that exist in the environment. Homestay has a concept like the house and the different forms of other existing accommodation. Here is some concept of homestay:

According to Lashley dan Morrison dalam Seubsamarn (2009) Homestay accommodation types include farmstay accommodation, some small hotels, host families, and bed and breakfasts. It is used to refer to types of accommodation where tourists or guests pay directly or indirectly to stay in private homes. According to Lynch dalam Seubsamarn (2009) In homestay accommodations, the boundaries of private homes are opened to public space, distinguishing from other accommodations which private space open to staff only. While Rivers in Seubsamarn (2009) Utilities and meals are usually included, and the length of stay could be daily, weekly, monthly, or unlimited unless specified otherwise by the host.

Rhodri in Seubsamarn (2009) explained that "distinction between homestay and hotel is the boundaries of private area. The private space of homestay is opened to visitors that would not fall under the term of hotel".

Based on some of these concepts, it can be concluded that according to Lashley and Morrison on homestay accommodation contained farmstay accommodation, the hotel features a small, family as well as the owner of a bed and meals where tourists or paid directly or indirectly to stay in private homes such. According to Lynch on homestay accommodation, private room in the house can be opened as a public space, different from other accommodation which only opens his private space for staff only. Rivers states that the utility homestay accommodation and meals are usually included, length of stay can be daily, weekly, monthly, and even not limited unless specified by the homeowner.

It implies that the difference between homestay and the hotel is a private area boundary. Private room in homestay is welcomed to visitors, this is in contrast with hotel accommodation. The concept of home is perceived at distinguishing homestay accommodation with other forms of accommodation. Based on the available data, it can be concluded that the homestay is the type of accommodation that use the residence as a place of stay, guests or tourists can pay directly or indirectly for guests staying home belonging to the host. In homestay accommodation rating can share together the host and his family, private room opened into a public space and include accommodations such as bed and breakfast.

\section{METHOD}

In this study, the authors used qualitative methods, where actual condition or state are described by collecting data and information in the field of narrative form without test hypotheses or predictions. (Rachmat, 1999).

According Wadiyanta (2006), it was explained that the operation was an information that is used by researchers to follow a variable which is the translation of a concept. The variables measured in this research is the cleanliness of the homestay, homestay facilities and comfort.

\section{RESULT}

\section{Petak Village Community}

According to the East Java Governor Decree No. 188.45 / 451 / HK / 416-012 / 2003 District Pacet is determined as agropolitan in Mojokerto regency, with seven villages namely Cepokolimo development, Claket, Pecan, Pacet, Padusan, Plots and Sajen.

Based on data from the District Pacet in Figures 2012, the major population in Petak district is farmers with agricultural areas that excel in food crops (rice and sweet potatoes) and horticulture crops (onions, garlic and mushroom). 
Besides, the village Community Grid is still preserved the culture and customs of the local village, including: a. budaya ruwah dusun, a ritual to the village in order to avoid or get away from danger, disaster, etc. b. budaya keleman, a tradition for villagers especially for farmers who want to plant (cultivation) rice. c. Budaya methik, a traditional ceremony especially for farmers who want to harvest rice.

\section{Home Stay Management in Pacet Village}

\section{Homestay Cleanliness}

Cleanliness can be understood as a condition which enables us to be free from dirt, such as dirt, dust, garbage and odors. Homestay cleanliness is crucial since it is one of the accommodations presented to travelers who are or who want to have leisure activities in a region. To find out the cleanliness homestay, there are three indicators to measure the cleanliness homestay, and room cleanliness, cleanliness of the bathroom / toilet and food hygiene (Aminudin and Rifiyan, 2015).

Below are the observation results from few houses that will be employed as homestays. As for the cleanliness, room taken from sample show that they are clean, fragrant and neat. For the bathrooms, despite the modest size of the house,the cleanliness of the bathrooms is well-maintained. Food are hygienic because the manufacturing process involves fresh ingredients and freshly served in the kitchen table. Based on the above observation, it can be concluded that most of the houses can be used as a Homestay.

\section{The Homestay Comfort}

Comfort is a feeling from the fulfillment of a condition that is individualized. Related with a sense of comfort, according Kolcaba (2003) comfort is associated with:

a. Physical comfort is associated with bodily sensations perceived by the individuals themselves.

b. Convenience psychospiritual is related to internal selfawareness, which includes the concept of self-esteem, the meaning of life, ranging from sexuality to a very close relationship and higher.

c. Comfortable environment is associated with the environment and the effect from external factors such as temperature, color, temperature, lighting, and sound.

d. The socio-cultural comfort is associated with interpersonal relationships, family, and social or community (financial, health care of individuals, religious activities, as well as a family tradition).

Comfort is required by the travelers staying in the homestay and utilizing the facilities provided by the homestays. To measure the comfort of a homestay, three indicators are used, namely convenience of service, comfort and convenience amenities culture (Aminudin and Rifiyan, 2015). For comfort in culture, it is very close with the interpersonal relationship between guest and host, where the comfort of this culture is determined by interaction between the guest and the host so that the behaviors or habits of people are very closely related with the comfort culture.

Another observations on services in some homes indicates that the host is serving his guests well, in spite of some improvements in service quality that still need to be performed . As for facilities, the hosts provide sufficient facilities for the guests. Some home amenities such as television, cabinets and chairs are available on most houses. With those observation, it can be concluded that most of the house can be used as a homestay in Pacet village.

\section{Homestay Security}

Security is a basic need of man that wants to have a sense of security and feel free from the sense of danger. Security in a place to stay should be taken into account, moreover, the security of the homestay is one category of a place to rest, including homestays. This study divides the top three security homestay indicators namely food safety, security and environmental safety homestay facilities (Aminudin and Rifiyan, 2015). Three indicators are used to determine the level of security in the region homestay village of Pacet.

Observations indicate that foods presented with good condition because the host make or cultivate food from preparation materials and processing until with presentation of food and beverage done properly in accordance with concept hygiene and sanitation. Similar with findings, observation security showed convenience has been used adequately. Environmental security to review the findings observations show that people in the village of Pacet are very concerned. People in the village will always be aware of environmental safety which is proven by very demonstrated lack of complaints addressed to the security community leaders, Based on the above analysis, it can be concluded that the security in the village of Pacet the houses can be used as Homestay or a place to stay for tourists who stay in the village of Pacet.

\section{Management Obstacles}

Obstacles encountered in managing the homestay is the absence of training management. Information on homestay is given to the public in order to avoid a form of competition between one homestay with another homestay, in order to avoid competition between communities which could lead to competition that are less well that can later be detrimental to the community itself, where it can degrade the cultural kinship and mutual cooperation that has existed since long Pecat village.

\section{CONCLUSION}

Based on the above discussion, this research can be concluded as follows:

a. Homestay program can be implemented in the village of Petak because most of the houses of the people have meet the homestay criteria based on cleanliness, comfort and security. This means that the culture of rural plots to preserve the cleanliness, comfort and safety has been running well.

b. Given the criteria for homestay such as cleanliness, comfort and security has become people's culture, however training on good homestay management needs to be done in order to avoid competition among communities that could cause unfavorable competition which will be detrimental to the community itself, 
where it can reduce the cultural kinship and mutual cooperation that has existed for a long time.

\section{REFERENCES}

Aminudin Ali Ria and Rifiyan Andi Arief, (2015), Pelaksanaan Pengelolaan Homestay Di Desa Lubuk Kembang Bunga Kawasan Eko Wisata Tesso Nilo Kabupaten Pelalawan Provinsi Riau, Jom FISIP, 2 (2) .

Asbullah, Alvan .S, M. S. Irhamsyah, Muhammad N. (2013). Eco-Homestay: Development Concept On Rural Tourism-Based Conservation Model(Study Case of Sidomulyo Village, Silo District, Jember Regency) Journal of Indonesian Tourism and Development Studies J.Ind. Tour. Dev. Std., 1 (3) ,123-127.

ASEAN Homestay Standard.(2016). Jakarta: ASEAN Secretariat.

Kolcaba, Katherine. (2003). Comfort Theory And Practice: A Vision For Holistic Health Care And Research: New York: Spinger Publishing Company.

Lama Minki.(2013). Community Homestay Programmes As A Form Of Sustainable Tourism Development In Nepal., Centria University Of Applied Sciences.Degree Programme in Tourism.,Thesis.
Lynch, P. A. (2005). The Commercial Home Enterprise and Host : a United Kingdom Perspective. International Jurnal of Hospitality Management 24 (533-553). Edinburgh : Elsevier.

Nirmala, Rini RW, Eko B. S. (2013). Keterkaitan Komoditas Unggulan antar Desa Kota dalam Pengembangan Kawasan Agropolitan Pacet-Mojokert. Jurnal Teknik Pomits, 2 (2), Issn: 2337-3539., 149-152.

Ori., nd. (2016). Garap Wisata, Desa Petak Gandeng STP Trisakti., Koran Radar Jatim.

Rakhmat, Jalaluddin. (1999). Metode Penelitian Komunikasi, Bandung : Remaja Rosdakarya.

Sweeney, M. (2008). An investigation into the host's relationship with the commercial home. $\mathrm{PhD}$ Thesis. Edinburgh : QueenMargaret University College. (tidak dipublikasikan)

Seubsamarn, K. (2009). Tourist Motivation to Use Homestay in Thailand and Their Satisfaction Based on The Destination's Cultural and Heritage Based Attribute. MSc Thesis. Missouri : Graduate School University. (tidak dipublikasikan)

Yoeti, Oka, A. (1985). Pengantar Ilmu Pariwisata. Angkasa Offset. Bandung.

http://slideplayer.info/slide/2306027/ 